\title{
Translator's Introduction
}

The identity of philosopher and king... is a noble lie, but it is not a lie of the city.

-Seth Benardete, Socrates' Second Sailing

In 1935 Karl Löwith, ${ }^{1}$ a gifted, well-educated German scholar of Jewish descent, first published in Berlin this classic of the Nietzsche literature. By then he had already emigrated to Italy after having endured, as a university docent in Marburg, over a year of National Socialism. Not accidentally, Nietzsche had served as the focal point of Löwith's final courses in Marburg: "I wanted to make clear to the students that Nietzsche prepares the way for, and at the same time represents the severest rejection of, the present situation in Germany. Nietzsche is a 'National Socialist' and a 'cultural Bolshevik'-depending on how one maneuvers him. In opposition to this usage that is

1. For a very thoughtful and sensitive portrait of Löwith by the man who brought him to Heidelberg after the war, see Hans-Georg Gadamer, Philosophische Lehrjahre (Frankfurt am Main: Vittorio Klostermann, 1977), pp. 231-239; translated as Philosophical Apprenticeships (Cambridge, Mass.: MIT Press, 1985), pp. 169-175. Arnold Levison provides a useful introduction to Löwith for English-speaking readers in his opening, editorial essay entitled "Nature and Existence" in Karl Löwith, Nature, History, and Existentialism and Other Essays in the Philosophy of History, ed. Levison (Evanston, Ill.: Northwestern University Press, 1966), pp. xv-xl. For those who cannot read German that collection of essays, together with From Hegel to Nietzsche: The Revolution in Nineteenth-Century Thought (New York: Holt, Rinehart and Winston, 1964) and Meaning in History 
suited or perhaps unsuited to the times, I tried to establish the idea of eternity as the center of his philosophy." 2

Löwith took advantage of the first year of a crucial Rockefeller Foundation Fellowship held during the years 1934-1936 to perfect his studies on Nietzsche in Rome. ${ }^{3}$ The 1935 decision by Gerhard Bahlsen, proprietor of the press "Die Runde," to publish Nietzsches Philosophie der ewigen Wiederkunft des Gleichen ("Nietzsche's Philosophy of the Eternal Return of the Same") in the capital of Hitler's Germany must have required both courage and some appreciation of the quality of Löwith's scholarship. By contrast, the journal Kantstudien declined in 1935 to publish Löwith's article on the relationship of Marx's to Kierkegaard's stance on Hegel-despite the editor's having formally accepted the piece a year earlier-for "technical reasons." As Löwith dryly observes in his memoir, the "technical reasons were that Marx was taboo in Germany and the author was not Aryan."

Nietzsche, of course, was by no means taboo in Germany in the 1930s. The Nazi Party went to some length to legitimate itself in the cloak of his authority, and Nietzsche's anti-Jewish sister, Elisabeth Förster-Nietzsche, proved only too willing to lend support to that unworthy purpose. Alfred Baeumler's crude depiction of Nietzsche as the philosopher of the "will as power," already published in 1931, served Party propaganda well and became more or less the official interpretation. ${ }^{5}$ In that context the political significance and daring of Löwith's pathbreaking work emerges unmistakably, for Löwith demonstrates here that the Nietzschean doctrine of the will to power is unintelligible apart from what Baeumler dismisses, the eternal recurrence of the same. Löwith did not shrink from making a harsh attack on Baeumler by name in section 7 of the Appendix, ${ }^{6}$ but for that very reason the entire Appendix had to be expunged before publication of the book could pro-

(Chicago: University of Chicago Press, 1949), offers the principal access to Löwith's work and thought. See also note 8 below.

2. Karl Löwith, Mein Leben in Deutschland vor und nach 1933: Ein Bericht (Stuttgart: J. B. Metzlersche Verlagsbuchhandlung, 1986), pp. 79, 137, 5-6. Hereafter cited as Leben.

3. Ibid., pp. 81, 104.

4. Ibid., p. 106. In 1936 Löwith could not find any German press for his book on Burckhardt, which was published in Switzerland by B. Schwabe.

5. Nietzsche: Der Philosoph und Politiker (Leipzig: Reclam Verlag, 1931). Baeumler was the official editor of Nietzsche's works during the Third Reich.

6. The Appendix can be found at pp. 195-229 below, with specific discussions of Bacumler and Heidegger at pp. 210-214 and 225-229. 
ceed. All twelve book reviews in the Appendix could only be circulated separately until 1956, when the revised and expanded second edition appeared in Stuttgart under the imprint of the W. Kohlhammer Verlag as Nietzsches Philosophie der ewigen Wiederkehr des Gleichen ("Nietzsche's Philosophy of the Eternal Recurrence of the Same").?

More serious than Baeumler by many orders of magnitude, but like him entangled with the Nazis nonetheless, Löwith's own teacher Martin Heidegger provides another target of severe and not altogether dispassionate criticism in the concluding section of the Appendix. Of course the critique included in this volume does not encompass Löwith's full assessment of Heidegger or even of his interpretation of Nietzsche. ${ }^{8}$ Heidegger's two-volume, 1,150-page tome entitled Nietzsche did not appear until 1961,9 whereupon Löwith published an extended, scorching review. ${ }^{10}$ The later review develops more fully and in a broader context the trenchant criticisms and probing questions raised at the end of the present book. At all events, the decisive influence on Löwith of Heidegger's mentorship remained indelible, as did the student's disapprobation of the master's cooperation with the $\mathrm{Na}$ tional Socialists. Löwith regarded Heidegger's collaboration as a consequence not just of his political naïveté or personality flaws but of his thought. Speaking of Heidegger's intellectual intensity and his concentration on "the one thing needful," Löwith asserts that this one thing was "a nothing, a pure resoluteness" that lies concealed beneath

7. The present translation is based on the authoritative third edition published by Felix Meiner Verlag in Hamburg in 1978. That edition incorporates corrections made in accordance with the author's handwritten manuscript. In 1986 the Meiner press issued a fourth edition that duplicates the third. Vol. 6 of the Sämtliche Schriften, entitled Nietzsche (Stuttgart: Metzlersche Verlagsbuchhandlung, 1987), collects all Löwith's publications on Nietzsche and includes a summary of his doctoral dissertation as well as a letter from Karl Schlechta in response to Löwith's reviews; the text of Nietzsches Philosophie in that volume follows the Meiner edition, albeit with occasional transcriptional errors.

8. The first edition of Löwith's Heidegger: Denker in diurftiger Zeit ("Heidegger: Thinker in a Destitute Time") reached the public in 1953 (Frankfurt am Main: S. Fischer Verlag), and release of the second, expanded edition occurred in 1960 (Göttingen: Vandenhoeck \& Ruprecht). The work has recently been made available in English translation, forming part of the volume of selections from Löwith published as Martin Heidegger and European Nibilism, ed. Richard Wolin, trans. Gary Steiner (New York: Columbia University Press, 1995). Vol. 8 of Sämtliche Schriften collects Löwith's public statements on Heidegger, including Denker.

9. Pfullingen: Verlag Günther Neske, 1961. David F. Krell's fine, four-volume English translation was published by Harper and Row (San Francisco, 1979-1986).

10. Merkur 16, no. 1 (1962): 72-83. Reprinted in Karl Löwith, Aufsätze und Vorträge, 1930-1970 (Stuttgart: Verlag W. Kohlhammer, 1971), pp. 84-99, and in Sämtliche Schriften, vol. 8 (Stuttgart: Metzler, 1984), pp. 242-257. 
Heidegger's quasi-theological approach. ${ }^{11}$ Man's "facticity" and mortality replace the immortality of the soul, and immanent, historically determined Being substitutes for the transcendent, eternal God Almighty, in this inverted, atheistic theology. Although Heidegger characterized his own struggle with the question of Being as an attempt "to develop fully what Nietzsche brought about," 12 Löwith contrasts the emptiness of Heideggerian resoluteness with Nietzsche's love of wisdom in persistently focusing on the whole of nature, on the eternal that always recurs because it remains the same in all alteration and change of the things that are.

Heidegger could have rejoined that he is more genuinely Nietzschean than is Nietzsche himself. Does not Heidegger, in eradicating every trace of eternity from his world, remain truest to the earth and least susceptible to the attractions of metaphysical "backworlds"? Does not Nietzsche, in proclaiming the affirmation of the eternal recurrence to be the peak of human existence and the secret for weaving the accident "man" back into the whole of Being, succumb to that very spirit of revenge (against the transient world of the senses) he warns against? And if the ontic status of the eternal recurrence depends on human affirmation or willing, does not precisely that teaching require a nontranscendental analysis of the emphatically transitory existence of the human being in his historicity? In other words, contra Löwith, does not Nietzsche's philosophy make Heidegger's necessary?-On the other hand, one can ask whether Heidegger accepts too uncritically what he considers to be Nietzsche's most fundamental parameters. The foundation of atheist theology is atheism, and Heidegger goes so far as to call faith the mortal enemy of philosophy. ${ }^{13}$ Does Heidegger ever

11. Leben, p. 29 and generally pp. 29-42; Sämtliche Schriften 8:61-68 and 297. Löwith's account of Heidegger's 1936 trip to Rome to present a lecture on Hölderlin deserves particular note: "I declared to Heidegger that . . . in my opinion his advocacy of National Socialism derives from the essence of his philosophy. Heidegger agreed with me without reservation and elaborated by telling me that his concept of 'historicity' is the foundation for his political commitment" (Leben, p. 57). Cf. Löwith's "Zu Heidegger's Seinsfrage: Die Natur des Menschen and die Welt der Natur," in Aufsätze und Vorträge, 1930-1970, pp. 189-203. Löwith found it hard to speak of his stance toward Heidegger's philosophical project "without including [my] personal relationship" to Heidegger (ibid., p. 192). p. 28.

12. Einführung in die Metaphysik, 4th ed. (Tübingen: Max Niemeyer Verlag, 1976),

13. "Phänomenologie und Theologic," in Gesamtausgabe, vol. 9, Wegmarken (Frankfurt am Main: Verlag Vittorio Klostermann, 1976), p. 66. See Heinrich Meier, Die Lebre 
demonstrate that the life of faith is based on an error, or does his philosophizing itself not rather rest on faith? Heidegger makes no secret of his higher esteem for the pre-Socratics than for Plato's Socrates, and on crucial matters Heidegger like the pre-Socratics not infrequently shows a dangerous, un-Socratic preference for issuing pronouncements from on high rather than elaborating intricate, rational arguments. ${ }^{14}$ The danger that attaches to Heidegger's failure to follow the Socratic turn by first of all challenging and then justifying with cogent arguments the philosophic way of life lies not so much in atheistic theology per se as in a self-destruction of philosophy, an ultimately unphilosophic "philosophy" based on faith. Thus Löwith's clarion call, in Nietzsche's name, for a return to nature from History can be said to have the most profound warrant after all.

Löwith composed the main text of Nietzsches Philosophie "sine ira et studio, without sentimentality or vagueness, and with competence and a natural grace." 15 Unlike Heidegger and Jaspers, ${ }^{16}$ who without regard for finer sensibilities do not hesitate to intrude themselves "creatively" into their portrayals of Nietzsche, Löwith loyally strives to

Carl Schmitts: Vier Kapitel zur Unterscheidung politischer Theologie und politischer Philosophie (Stuttgart: Verlag J. B. Metzler, 1994), p. 136 note 48, and in general pp. 13186.

14. Admittedly, circumstances that warrant writing between the lines-persecution, for example, or certain pedagogical requirements-can sometimes fully excuse a writer's failure to make explicit the rigorous arguments that lead to his conclusions, to say nothing of the ultimate conclusions themselves. See, for example, Löwith's "Skepticism and Faith," in Nature, History, and Existentialism, pp. 120-121: "Sextus Empiricus . . . $s a y[s]$ that the skeptic, for reasons of benevolence, tries to cure the dogmatists by way of persuasion. However, just as physicians administer medicines of different strengths, according to the seriousness of the ailment, the skeptic's arguments, too, have to be lighter or stronger depending on how superficial or deep-rooted the dogmatist's folly is. For this reason the skeptic, intentionally, does not refrain from using weak arguments occasionally." See also Leo Strauss, Persecution and the Art of Writing (New York: The Free Press, 1952), pp. 7-37. But as Löwith recognizes, these considerations have no vindicatory bearing on Heidegger, for in spite of the enormous difficulties involved in coming to grips with his corpus, he may well be the least ironic, least esoteric of all the great thinkers in the philosophic tradition.

15. Leo Strauss, What Is Political Philosophy? and Other Studies (Glencoe, Ill.: The Free Press, 1959), p. 268.

16. Karl Jaspers, Nietzsche: Einführung in das Verständnis seines Philosophierens, 3d ed. (Berlin: Walter de Gruyter, 1950). Translated as Nietzsche: An Introduction to the Understanding of His Philosophical Activity, trans. Charles F. Wallcraft and Frederick J. Schmitz (Tucson: University of Arizona Press, 1965). 
interpret Nietzsche's oeuvre authentically from within and as a whole. ${ }^{17}$ Accordingly, he takes full cognizance of the aphoristic, seemingly fragmented character of many major writings of Nietzsche and of Nietzsche's disdain for the will to systematize as betokening a lack of integrity, ${ }^{18}$ while simultaneously treating seriously Nietzsche's claim to have a single concern and a whole teaching and vision. ${ }^{19}$ As Löwith persuasively argues, "Nietzsche's philosophy is neither a unified, closed system nor a variety of disintegrating aphorisms, but a system in aphorisms." 20 To be sure, in important respects Nietzsche's understanding changed and above all deepened; but Löwith shows that the earlier phases, Nietzsche's romanticism and positivism, were not so much supplanted as completed by the mature phase of the eternal recurrence. ${ }^{21}$

Loyalty to the text does not at all hinder Löwith from taking a critical view of the Nietzschean accomplishment, however. True, he masterfully articulates the connections between most main themes in Nietzsche-nihilism, the superman, courage, the will to power, the revaluation of all values, amor fati, death, the last man, the death of God-and the overarching motif of the eternal recurrence. ${ }^{22}$ Nevertheless, the central thesis of the present work is that that very overarching conception or red thread which provides the key to grasping Nietzsche's system qua system contains a discord that ultimately causes the entire fabric to unravel tragically beyond repair. Löwith makes clear that the ostensibly unified allegory of eternal recurrence splits into two irreconcilable parts, one cosmological and the other anthropological-one portraying the goalless revolution of the universe, the other, a superhuman act of the human will that consummates the self-overcoming of nihilism. In its cosmological mode the eternal recurrence represents a natural-scientific "fact" consisting of the goalless, self-contained existence of the world of forces. In its anthropomorphic mode the recurrence signifies an ethical gravity that gives goalless human existence a goal again. (In particular, the teaching of recurrence is meant to re-

17. Hence Löwith includes what is probably a far greater number of direct quotations of Nietzsche, especially of quite lengthy ones, than can be found in any other commentary. The present translation often relies, with occasional emendations, on the generally superb renditions of Nietzsche's writing by Walter Kaufmann.

18. Twilight of the Idoks, "Maxims and Arrows," aph. 26.

19. See, e.g., On the Genealogy of Morals, preface, aphs. 1-2; notes 29-33 to chap. 1 below.

20. P. 11, and more generally pp. 11-20, below.

21. Pp. 21-26 and pp. 27-107 below.

22. Pp. 27-136 and 174-192 below. 
constitute and elevate humanity by means of the new categorical imperative: live in every moment so that you could will that moment back again over and over endlessly.) So on the one hand the recurrence as unwilled, physical fact replaces ancient cosmology with modern physics; but on the other hand the recurrence as the willing of an ideal replaces Christian faith in the afterlife with the will to self-eternalization and a new way of life. "This double explicability as an atheistic religion and as a physical metaphysics shows that in its totality the teaching is the unity of a conflict between the nibilistic existence of the man who has rid himself of God and the positivistic presence of physical energy."23 Löwith leaves little doubt that the doctrine of eternal recurrence shatters into incommensurable shards, for one need not will a fact, and the knowledge that one wills a fiction necessarily undermines the believability of what one wills. The huge structure of Nietzschean metaphysics crashes so resoundingly and so hopelessly under Löwith's powerful assault that one might wonder in the aftermath: Did Nietzsche completely overlook this fundamental flaw in his teaching of eternal recurrence? Or could that flaw point to a deeper, far less manifest teaching? In Thus Spoke Zarathustra II, "On Redemption," Zarathustra instructs his disciples about how to bring about redemption from the past and from the spirit of revenge against the past, namely by creatively willing the past as one's own creation. This memorable speech obviously makes a preliminary announcement of amor fati, of the necessity of willing the eternal recurrence. As Löwith does notice, an astute hunchback objects here that Zarathustra speaks differently both to hunchbacks and to himself than he does to his pupils. Zarathustra's discourse about the eternal recurrence is evidently exoteric-esoteric. Löwith appears to take no notice of the fact that of all human beings an astute hunchback is least likely to be hoodwinked by implausible tales of the redemptive will.

Löwith supplements, not to say embellishes, his interpretation proper with a series of learned reconstructions that locate Nietzsche within the history of thought, principally in the modern period. Of the various ancients who spoke of an eternal cycle of things-Heraclitus and Empedocles, Plato and Aristotle, Eudemus and the Stoics-Heraclitus's philosophy wins the laurels as the primary antique model for Nietzsche's eternal recurrence. Nietzsche sees in Heraclitus the highest form of pride, and justice prevails as the supreme law of necessity in 
Heraclitus's eternal process of becoming. Christianity, of course, comprises Nietzsche's antipode, signaling a momentous revaluation of values by the victorious slave morality of the antiaristocratic, vulgar multitude. In Löwith's view Nietzsche never truly overcomes Christianity, however, but remains trapped in an antinatural, Christiananti-Christian perspective directed at redemption in the future. As for the "modern historical consciousness," in Löwith's cast of characters Nietzsche is "the first" to take his bearings by the eternal. The grave difficulty confronted by all moderns concerns the problematic relationship between human existence and the Being of the world. Especially with a view to the development of the "historical consciousness," one might reasonably describe that difficulty as the problem of how to establish a basis for human freedom and morality in a world of ineluctable, universal, mechanistic causation that in principle allows no room for a distinct, human empire within an empire. Spinoza seems to escape Löwith's attention, however, perhaps because Descartes serves as a substitute. (In the spirit of Aristotle and with a bow to Husserl, Löwith could have pointed out that whereas the thesis of universal mechanism-though of great utility for centuries of progress in modern natural science and technology-allows of no apodictic proof, on the level of consciousness the thesis of human freedom that is so vital to morality can be directly verified through immediate, personal experience by the human being who persistently deliberates over choices.) In any case Descartes's insistence on clarity as the criterion of truth and his consequent mathematization of the world does much to liberate humanity and philosophy from ecclesiastical authority. But Descartes's ostensible quest for irrefragable certainty leads him to distinguish between man the thinking being who has certainty about his own existence, and the corporeal world that finally remains uncertain. Ever since, man has tried to construct a bridge between the human ego and the world. Although Nietzsche regards Descartes's faith in reason and in immediate certainty as naive and superficial, in Löwith's historical interpretation the discord in Nietzsche's eternal recurrence emanates from the duality of Cartesian subjectivism. Kant only deepens the bifurcation begun by Descartes. Fichte tries to bind the ego and the eternal natural world by means of faith in a divine will and divine providence-for Nietzsche a nonsolution after the death of God. Löwith calls Schelling, who affected Nietzsche only indirectly through Schopenhauer and von Hartmann, the only thinker within German idealism with a positive relationship to Nietzsche's eternal return. For Schelling the comprehensive, 
primeval being of nature develops purely out of itself through its own drive and desire, remains present always, and outlasts everything that once was. This primal nature continues in constant, rotating motion that neither begins nor ends, and seeks only itself. But Schelling, too, posits divine will as the source of human freedom. In Hegel's thought, nature has no original, independent meaning. In his quarrel with Kant, Fichte, and Schelling, Hegel tries to restore the lost unity of man and world in a philosophy of absolute spirit. Löwith maintains that absolute spirit takes the place of God, and that the philosophy of absolute spirit only makes man's separation from the world more visible. The reader may regret the lack of a fuller treatment of Nietzsche's relationship to Rousseau by way of Goethe on the one hand and Kant and Hegel on the other, but Löwith does address this theme more extensively in From Hegel to Nietzsche. Considering the space devoted to Stirner, Marx, Weininger, and Kierkegaard, ${ }^{24}$ however, the astonishing neglect of the most towering philosopher of antiquity and pivotal figure of Nietzsche's thought is all the more striking.

Löwith's imposing scholarship, a treasure trove of sober reflection and elegant expression, will likely remain in the forefront of commentaries for many generations. No serious student of Nietzsche can afford to ignore the achievement of this book. Nevertheless, one must consider that the author uncharacteristically and conspicuously disregards a central Nietzschean theme of the greatest consequence: Nietzsche's relationship to Socrates. ${ }^{25}$ Disconcertingly, Löwith refers to Plato fewer than a half-dozen times and, even more strangely, to Socrates only once-only to subordinate him completely to Heraclitus. By contrast, Nietzsche's own writings, including the literary remains, are replete with discussions of both Plato and Socrates. In 1875 Nietzsche says, "Socrates, just to confess it, stands so close to me that I almost always fight a battle with him." 26 From The Birth of Tragedy, where Socrates as the antihero gets the blame for the destruction of Greek

24. Pp. 150 173 below.

25. See Kurt Hildebrandt, Nietzsches Wettkampf mit Sokrates und Plato (Dresden: Sibyllen Verlag, 1922); Werner Dannhauser, Nietzsche's View of Socrates (Ithaca, N.Y.: Cornell University Press, 1974); and Lawrence Lampert, Nietzsche's Teaching: An Interpretation of Thus Spoke Zarathustra (New Haven: Yale University Press, 1986), esp. p. 168.

26. Kritische Studienausgabe, vol. 8 (Munich: Deutscher Taschenbuch Verlag, 1980), p. 97. Does Nietzsche, by calling the whole, ossified philosophic tradition into question and thus making possible and pursuing a fresh, truly philosophic confrontation with the most fundamental issues, earn the title of Socratic philosopher? 
tragedy, to Twilight of the Idols, where in the chapter entitled "The Problem of Socrates" he continues to play a key role, Nietzsche struggles with his chosen companion and antagonist, whom he calls the vortex of world history. It is true that Thus Spoke Zarathustra never explicitly mentions either Plato or Socrates. But the same does not hold for Nietzsche's two elaborations of Zarathustra, namely, Beyond Good and Evil and On the Genealogy of Morals. Moreover, the last three aphorisms (340-342) of Part IV of The Gay Science suggest significant ligatures between Socrates, the eternal recurrence of the same, and Zarathustra. Also, in aphorism 340 Nietzsche describes Socrates as the wisest chatterbox there ever was, and then adds that he was just as great in his silence. Löwith's seeming indifference notwithstanding, one has to call Nietzsche's characterization of Socrates extraordinary, and one has to move him to front and center stage. Undeniably, Löwith-by being as faithful to Nietzsche as he is-pioneers a path to the only vista where Nietzsche's kaleidoscope of lovely fragments suddenly comes to view as a breathtaking, intelligible work of art. But in the end he fails to disclose the full meaning and beauty of that artistic masterpiece and riddle, because he does not see it in the transfiguring light of the Platonic Socrates. 